\title{
Testing of Bacterial Endophytes from Non-Host Sources as Potential Antagonistic Agents against Tomato Wilt Pathogen Ralstonia solanacearum
}

\author{
Pious Thomas*, Reshmi Upreti \\ Division of Biotechnology, Indian Institute of Horticultural Research, Hessarghatta Lake, Bangalore, India \\ Email: ${ }^{*}$ pioust@gmail.com; pioust@iihr.ernet.in
}

Received 16 June 2014; revised 12 July 2014; accepted 6 August 2014

Copyright (C) 2014 by authors and Scientific Research Publishing Inc. This work is licensed under the Creative Commons Attribution International License (CC BY). http://creativecommons.org/licenses/by/4.0/

(c) (i) Open Access

\section{Abstract}

The study was taken up with the objective of testing whether the endophytic organisms isolated from crops that are normally non-hosts to the bacterial wilt pathogen Ralstonia solanacearum possessed pathogen-antagonistic activity and to evaluate the selected isolates for the alleviation of wilt disease in the target tomato crop through horizontal movement of promising organisms. Sixteen endophytic bacteria (EB) isolated from the micropropagated cultures of grape, watermelon and papaya were tested for potential antagonistic effects against $R$. solanacearum tomato isolate "NH-01" through agar-well diffusion assay. Enterobacter cloacae from papaya (EB-11) displayed the maximum antagonistic effect followed by Bacillus subtilis (EB-06) and B. flexus (EB-07) from watermelon and $B$. pumilus (EB-02) from grape. Testing the above organisms for crop protection through seed fortification of susceptible tomato cv. Arka Vikas at sowing in $R$. solanacearum inoculated (Ral+) organic cocopeat showed EB-02 and EB-11 promising (33\% and 32\% survival, respectively, four weeks after sowing against $15 \%$ in Ral+ control). A second trial showed $37 \%, 28 \%$, $21 \%$ and $55 \%$ seedling survival 6 weeks after sowing for EB-02, EB-06, EB-07 and EB-11 respectively, compared to $2.5 \%$ in non-treated control. Assessing the four endophytes for crop protection in Ral+ sick-soil through seedling fortification at transplanting indicated less disease incidence in treated sets $(40 \%, 40 \%, 20 \%$ and $20 \%$ survival, respectively, six weeks after transplanting) over non-fortified control (5\%). Endophytic fortification of seedlings through hypocotyl inoculation showed some systemic resistance induction upon seedling transplanting to sick soil but not with petiole fortification. Seedling growth was enhanced by the isolates EB-06 and EB-07. The study thus identifies four endophytic organisms from crops unrelated to tomato possessing potential antagonistic activity against the wilt pathogen and prospects for exploitation as biocontrol agents coupled with seedling growth promotion effects.

\footnotetext{
${ }^{*}$ Corresponding author.
}

How to cite this paper: Thomas, P. and Upreti, R. (2014) Testing of Bacterial Endophytes from Non-Host Sources as Potential Antagonistic Agents against Tomato Wilt Pathogen Ralstonia solanacearum. Advances in Microbiology, 4, $656-666$. 


\section{Keywords}

\section{Bacterial Wilt, Biocontrol, Endophytic Bacteria, Growth Promotion, Solanum lycopersicum}

\section{Introduction}

Bacterial wilt caused by Ralstonia solanacearum (formerly called Pseudomonas solanacearum) is one of the major limiting factors in the cultivation of tomato and other solanaceous crops in the tropics and subtropics worldwide [1] [2]. The wide host range of this pathogen, soil- and water-borne nature and the adaptability to survive in soil in the absence of host plants for long periods make the control of this disease very challenging [1]-[4]. The common management strategies include the adoption of resistant varieties, crop rotation and the use of resistant root stocks [1]-[6].

Biocontrol approach exploiting microorganisms with antagonistic activity against the pathogen assumes significance as an alternate strategy for the management of plant diseases [7]-[9]. In the case of $R$. solanacearum, this includes the usage of rhizospheric colonizers [10]-[12] and the endophytic organisms [9] [13]-[15]. Competitive rhizospheric colonization, niche exclusion, substrate competition and production of secondary metabolites including antibiotics and siderophores are attributed in the control of pathogens by the antagonistic bacteria [7] [8] [16]. Endophytic microorganisms colonize plants internally and they share an integral and inseparable association with the host [7] [16] [17]. They are known to colonize the vascular system which forms the niche for the wilt pathogen too [15] [16] [18] [19]. Extensive colonization of plant tissue by the endophytes create a barrier-effect whereby they compete and prevent pathogenic organisms from establishing themselves [7] [16]. Endophytes are generally considered to be predominantly root colonizers [8] [16] [18] [20]. Extensive colonization of shoot tissue by bacterial endophytes including intracellular cytoplasmic and periplasmic niches has been documented recently [21].

At this laboratory, a number of endophytic bacteria were isolated as tissue culture-associated organisms from different crop species such as grape [22] [23], watermelon [24] and papaya [25]. Several of these organisms have been hardy spore-formers which offer the advantage of developing durable spore-based formulations. Endophytic organisms associated with other plant species if they possess antagonistic activity against the pathogen, they could be considered as potential biocontrol agents in the target susceptible crop through their lateral introduction. This is on the assumption that the susceptible target genotype may not naturally possess such antagonistic organisms or the specific isolates. This advantage applies particularly to the organisms isolated from crops that are unrelated to the target crop or are normally non-hosts to the pathogen. Among the above crops, papaya may be affected [10] [26] but is not a very common known host, while others are not known as normal hosts. The present study was taken up with the objective of screening a select group of endophytic organisms isolated from crops such as grape, watermelon and papaya for potential antagonistic activity against this pathogen and to test the utility of the selected organisms in alleviating the bacterial wilt disease in tomato.

\section{Materials and Methods}

\subsection{Endophytic Organisms}

Sixteen endophytic bacterial isolates (EB) from crop sources which are normally non-hosts to the pathogen, namely, grape, watermelon and papaya (coded as EB01 - EB16) were taken up for screening towards any antagonistic activity against the bacterial wilt pathogen. The EB isolates included Bacillus pumilus and Brevibacillus sp. isolated from in vitro grown grape as alcohol-resistant spore-formers [22] [23], B. megaterium, B. fusiformis, B. pumilus, B. subtilis and B. flexus from triploid watermelon culture again as alcohol-tolerant organisms [24], and Microbacterium esteraromaticum, Pantoea ananatis, Enterobacter cloacae, Brevundimonas aurantiaca, Bacillus benzoevorans, Sphingomonas sp., Methylobacterium rhodesianum and Agrobacterium tumefaciens from papaya shoot-tip cultures [25] (Table 1). The isolates were maintained as glycerol (20\%) stocks at $-80^{\circ} \mathrm{C}$ and revived by spotting the cultures on nutrient agar (NA) one or two days prior to their use in different trials. 
Table 1. List of endophytic bacteria isolated from micropropagated stocks of different plant species employed in Ralstonia solanacearum antagonism trials.

\begin{tabular}{|c|c|c|c|c|c|c|}
\hline EB No. & Identity of the organism & Isolate & Crop source & $\begin{array}{l}\text { NCBI 16S } \\
\text { rRNA gene seq. } \\
\text { acc no. }\end{array}$ & Reference & Description \\
\hline EB-01 & Brevibacillus sp. & ARBG1 & Grape & DQ 116777 & [23] & Gram - ve spore former \\
\hline EB-02 & Bacillus pumilus & ARBG2 & Grape & AY496869 & [22] & Gram + ve spore former \\
\hline EB-03 & Bacillus megaterium & 3xWMARB-1 & Watermelon & NA & [24] & Gram + ve spore former \\
\hline EB-04 & Bacillus fusiformis & 3xWMARB-2 & Watermelon & DQ306025 & [24] & Gram + ve spore former \\
\hline EB-05 & Bacillus pumilus & 3xWMARB-3 & Watermelon & DQ306026 & [24] & Gram + ve spore former \\
\hline EB-06 & Bacillus subtilis & 3xWMARB-4 & Watermelon & DQ306027 & {$[24]$} & Gram + ve spore former \\
\hline EB-07 & Bacillus flexus & 3xWMARB-5 & Watermelon & DQ306024 & {$[24]$} & Gram + ve spore former \\
\hline EB-08 & Bacillus pumilus & 3xWMARB-6 & Watermelon & NA & - & Gram + ve spore former \\
\hline EB-09 & $\begin{array}{l}\text { Microbacterium } \\
\text { esteraromatiucm }\end{array}$ & Pap.ViBa-1 & Papaya & DQ346728 & [25] & Gram + ve Actinobacterium, \\
\hline EB-10 & Pantoea ananatis & Pap.ViBa-2 & Papaya & EF088342 & [25] & Gram - ve $\gamma$-proteobacterium \\
\hline EB-11 & Enterobacter cloacae & Pap.ViBa-3 & Papaya & EF088345 & [25] & Gram - ve $\gamma$-proteobacterium \\
\hline EB-12 & $\begin{array}{c}\text { Brevundimonas } \\
\text { aurantiaca }\end{array}$ & Pap.ViBa-4 & Papaya & DQ346729 & [25] & Gram - ve $\alpha$-proteobacterium \\
\hline EB-13 & Bacillus benzoevorans & Pap.ViBa-5 & Papaya & DQ346730 & [25] & Gram + ve spore former \\
\hline EB-14 & Sphingomonas sp. & Pap.ViBa-6 & Papaya & DQ346734 & [25] & Gram - ve $\alpha$-proteobacterium \\
\hline EB-15 & $\begin{array}{l}\text { Methylobacterium } \\
\text { rhodesianum }\end{array}$ & Pap.ViBa-7 & Papaya & DQ346736 & [25] & Gram - ve $\alpha$-proteobacterium \\
\hline EB-16 & $\begin{array}{l}\text { Agrobacterium } \\
\text { tumefaciens }\end{array}$ & Pap.ViBa-8 & Papaya & DQ346737 & [25] & Gram - ve $\alpha$-proteobacterium \\
\hline
\end{tabular}

NA, not available.

\subsection{Culture of Pathogen}

Ralstonia solanacearum strain "NH01" (NCBI Acc. no. KJ399970) isolated from the bacterial ooze of a wilted tomato plant [27] constituted the pathogen unless mentioned differently. The culture was stored as glycerol stocks at $-80^{\circ} \mathrm{C}$ and revived on Kelman [28] medium fortified with 2, 3, 5 triphenyl tetrazolium chloride (KM-TTC) as described elsewhere [29]. An additional isolate of $R$. solanacearum "IH-01" was used for confirmation of antagonistic assay results in vitro.

\subsection{Media and Culture Conditions}

KM-TTC medium was used for raising the culture of pathogen while NA was employed for growing the EB isolates. Pre-sterilized single-use $9 \mathrm{~cm}$ plates were used for raising the cultures of both the pathogen and the endophytes whereas $12 \times 12 \mathrm{~cm}$ square plates were employed in antagonism trials. Both the above were sourced from Hi Media Biosciences, Mumbai.

\subsection{Agar-Well Diffusion Assay to Test Pathogen-Antagonistic Activity by Endophytic Organisms}

The lawn of pathogen was prepared in square plates (60 - $70 \mathrm{ml} \mathrm{KM-TTC} \mathrm{medium} \mathrm{per} 12 \times 12 \mathrm{~cm}$ plate) by spreading $200 \mu \mathrm{l}$ of $0.1 \mathrm{OD}(600 \mathrm{~nm}) \mathrm{R}$. solanacearum "NH-01" culture derived from 2-day old KM-TTC source plates. Prior to the introduction of challenge organisms, $R$. solanacearum was allowed to establish on KM-TTC medium for $3-4 \mathrm{~h}$ at $30^{\circ} \mathrm{C}$. Wells of $7-8 \mathrm{~mm}$ diameter (approx.) were made with the distal end of a sterile $200 \mu \mathrm{l}$ disposable pipette-tip and $50 \mu \mathrm{l}$ of $0.2 \mathrm{OD}(600 \mathrm{~nm})$ suspension of EB isolates $(01-16)$ prepared 
from 1 - 2 day-old NA plate cultures was added in marked wells. After incubation at $30^{\circ} \mathrm{C}$ for $2-4$ days, the plates were scored for the extent of zone of inhibition. The experiment was repeated twice for confirmation including the additional isolate "IH-01".

\subsection{Testing the Promising Endophytes for Crop Protection through Seed Fortification}

Based on the outcome from agar-well diffusion assay, four isolates namely EB-02 (Bacillus pumilus), EB-06 (B. subtilis), EB-07 (B. flexus) and EB-11 (Enterobacter cloacae) were taken up for further trials to check the ability of the organisms to protect the tomato crop. Cultivar Arka Vikas, which is highly susceptible to the pathogen [27] was employed as the target plant. Seeds were fortified with single endophytes by soaking in bacterial inoculum prepared in sterile water $(0.1 \mathrm{OD}$ at $600 \mathrm{~nm})$ for $1 \mathrm{~h}$ and they were sown in organic cocopeat (CP) [27] in 50 cavity protrays at the rate of 4 seeds per cavity (approx. $5 \mathrm{~g} \mathrm{CP}$ ) after removing the excess liquid inoculum. The CP was inoculated by applying $5 \mathrm{ml}$ of 0.1 OD suspension of $R$. solanacearum prepared in autoclaved water from 2-day KM-TTC plate cultures [27]. There were two control treatments, namely endophyte non-fortified seeds sown in Ralstonia inoculated or non-inoculated CP (Ral+ and Ral- control, respectively). Ten replications were employed per treatment with five cavities forming one replication. Separate trays were employed for different treatments to avoid the cross spreading of inoculum across different treatments. Trays were incubated in a glasshouse under identical conditions and seed germination was recorded after 7 and 10 days. The disease incidence (\%) was recorded after 2, 3 or 4 weeks based on the extent of irreversible wilting or seedling mortality [27]. The experiment was repeated thrice, twice as above and the next time employing CP that was inoculated with pathogen a week prior to the date of sowing.

\subsection{Assessing Selected Endophytes for Crop Protection Capability at Transplanting}

Seedlings of Arka Vikas were grown in fresh CP medium in 98 cavity protrays and were transplanted at 4 weeks stage with the intact ball of CP to Ralstonia sick soil in 50 cavity protrays as per Thomas and Upreti [29]. Two days prior to transplanting, the seedlings were fortified by drenching with $2 \mathrm{ml}$ of 0.1 OD suspensions of the isolates EB-02, EB-06, EB-07 or EB-11. Following transplanting, the root zone was again drenched with $5 \mathrm{ml}$ endophyte inoculum. The seedlings were incubated under glasshouse conditions and the disease incidence was recorded weekly for six weeks [29]. There were five replications per treatment with four plants constituting one replication. The experiment was repeated once.

\subsection{Testing the Endophytic Isolates for Any Direct Adverse Effects on Tomato}

Considering that the endophytes employed in this study were derived from other plant species, they were tested for any pathogenic effect on tomato by petiole-excision inoculation of seedlings [27]. The seedlings were grown in 5" plastic pots and at 4 week stage, the lower most green leaf was excised and a $10 \mu$ droplet of 0.1 OD inoculum prepared in sterile water was deposited. There were two control treatments, namely, seedlings applied with sterile water or with $R$. solanacearum inoculum.

\subsection{Testing the Capability of Organisms to Induce Systemic Resistance}

This was done on 4 week old seedlings two days prior to their transplanting to Ralstonia sick soil through petiole-excision inoculation as well as hypocotyl inoculation. In the first trial, the petiole was excised and a $10 \mu l$ droplet of 0.1 OD inoculum was applied as mentioned above. In the latter, the seedlings were given a hypodermic injection with approx. $10 \mu \mathrm{EB}$ inoculum at the lower part of the hypocotyl. The control sets were injected with sterile water. There were 20 seedlings per treatment and the seedlings were transplanted to Ralstonia sick soil in 50 cavity protrays [29].

\subsection{Testing the Selected Organisms for Growth Promotion Effects on Tomato Seedlings}

The four selected EB isolates were tested for growth promotion effects on "Arka Vikas” at seedling stage. The seeds were soaked in 0.1 OD bacterial suspension for $1 \mathrm{~h}$ and then sown in CP in 98 cavity protrays. Germination was recorded after 10 days and the seedling growth was assessed based on shoot height and the fresh weight of root, shoot and the whole seedling through destructive sampling 4 weeks after sowing [29]. 


\subsection{Statistical Methods}

The trials were conducted in completely randomized design under glasshouse conditions. The experimental conditions and data analysis were as described earlier [27] [29].

\section{Results}

\subsection{Agar-Well Diffusion Assay Employing Endophytic Organisms}

Four endophytic isolates, namely EB-02 (Bacillus pumilus) from grape, EB-06 (B. subtilis) and EB-07 (B. flexus) from watermelon and EB-11 (Enterobacter cloacae) from papaya displayed clear inhibition zone development against $R$. solanacearum while four other isolates (EB-08, EB-09, EB-10, EB-13) displayed slight zone of inhibition (Figure 1). The results with the first four isolates appeared consistent in two repeat trials which also held well with the second isolate, "IH-01" (Figure 1). EB-15 (Methylobacterium sp.) was not included in this trial as it was a very slow grower. Based on the extent of clear zone development, the organisms were categorized into four groups constituting EB-11 in group-1 displaying notable inhibition zone development, EB-02, EB-06 and EB-07 in group-2 showing obvious inhibition zone, EB-08, EB-09, EB-10 and EB-13 in group-3 with negligible zone of inhibition (EB-08 showed some inconsistency), and the rest in group-4 (Table 2). It was significant to note that although there were three B. pumilus isolates (EB-02, EB-05 and EB-08), only one isolate (EB-02 from grape) showed clear and consistent inhibition-zone development.

\subsection{Testing the Promising Endophytes for Crop Protection through Seed Fortification}

In the trial where the seeds were sown in freshly pathogen-inoculated CP after fortification with EB-02, EB-06, EB-07 or EB-11, germination was unaffected except in EB-11 where it showed a notable reduction (Table 3). The control seeds (EB non-fortified set) did not show notable differences in percent germination in Ral+ and

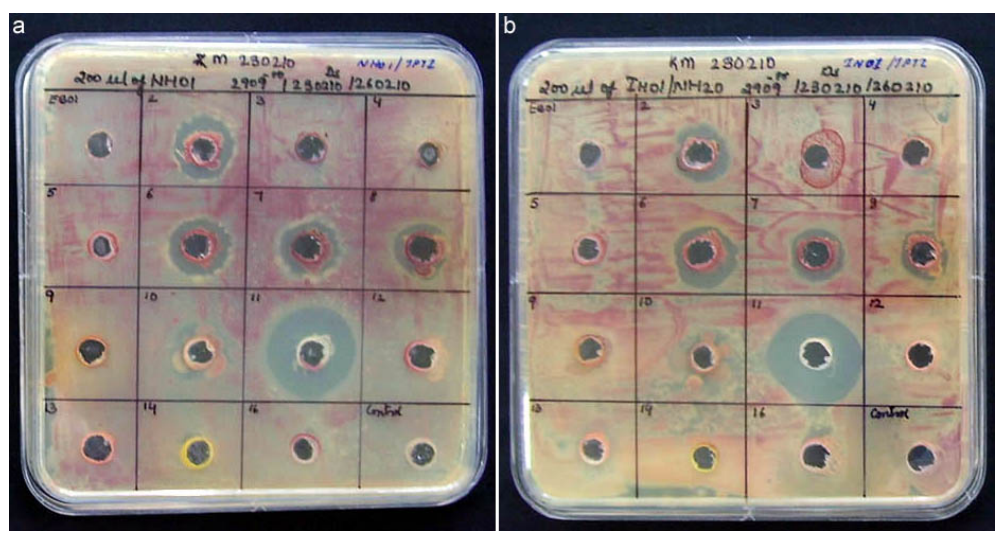

Figure 1. Agar-well diffusion assay to test pathogen-antagonistic activity against Ralstonia solanacearum by fifteen endophytic organisms marked 1 16 (excluding EB-15 which showed very slow growth) plus distilled water control; Prominent clear-zone development by the endophytic bacterial isolate EB-11 followed by EB-02, EB-06 and EB-07 in the trial employing the isolate "NH-01" (a) or the isolate "IH-01" (b).

Table 2. Classification of endophytic organisms based on the extent of clearing/antagonistic effect against Ralstonia solanacearum in agar-well diffusion assay.

\begin{tabular}{cccc}
\hline No. & Antagonistic effect & Clear zone diameter & Isolates \\
\hline 1 & Notable inhibition zone development & $>20 \mathrm{~mm}$ & EB-11 \\
2 & Obvious inhibition zone development & $15-20 \mathrm{~mm}$ & EB-02, EB-06, EB-07 \\
3 & Slight inhibition zone development & $10-15 \mathrm{~mm}$ & EB-08, EB-09, EB-10, EB-13 \\
4 & No inhibition zone development & None & EB-01, EB-03, EB-04, EB-05, EB-12, EB-14, EB-15, EB-16 \\
\hline
\end{tabular}


Table 3. Extent of seed germination and the incidence of seedling mortality in tomato "Arka Vikas" after sowing the endophyte-fortified seeds in freshly pathogen inoculated cocopeat (a), or inoculated one week prior to the sowing (b).

\begin{tabular}{|c|c|c|}
\hline \multirow{2}{*}{ Aspect } & \multicolumn{2}{|r|}{ Treatment } \\
\hline & Control: Ral-CP & Control: Ral+ CP EB02/Ral+ CP EB06/Ral+ CP EB07/Ral+ CP EB11/Ral+ CP \\
\hline
\end{tabular}

Freshly pathogen inoculated cocopeat

Seed germination $(\%)$

\begin{tabular}{|c|c|c|c|c|c|c|}
\hline Day 7 & $85^{\mathrm{a}}$ & $80^{\mathrm{a}, \mathrm{b}}$ & $77.5^{\mathrm{a}, \mathrm{b}}$ & $85^{\mathrm{a}}$ & $85^{a}$ & $67.5^{b}$ \\
\hline Day 10 & $92.5^{\mathrm{a}}$ & $82.5^{\mathrm{a}, \mathrm{b}}$ & $85^{\mathrm{a}, \mathrm{b}}$ & $87.5^{\mathrm{a}}$ & $90^{\mathrm{a}}$ & $72.5^{\mathrm{b}}$ \\
\hline
\end{tabular}

Seedling mortality (\%)

2 week
4 week
6 week

\begin{tabular}{|c|c|c|c|c|c|c|}
\hline Day 7 & $82.5^{a}$ & $75^{a}$ & $82.5^{\mathrm{a}}$ & $82.5^{\mathrm{a}}$ & $77.5^{\mathrm{a}}$ & $82.5^{\mathrm{a}}$ \\
\hline Day 10 & $92.5^{\mathrm{a}}$ & $80^{b}$ & $87.5^{\mathrm{a}, \mathrm{b}}$ & $87.5^{\mathrm{a}, \mathrm{b}}$ & $82.5^{\mathrm{b}}$ & $97.5^{\mathrm{a}}$ \\
\hline
\end{tabular}

Seedling mortality (\%)

\begin{tabular}{|c|c|c|c|c|c|c|}
\hline 2 week & 0 & $16.6^{\mathrm{a}}$ & $0^{\mathrm{b}}$ & $5.8^{\mathrm{b}}$ & $8.3^{\mathrm{a}, \mathrm{b}}$ & $7.5^{\mathrm{a}, \mathrm{b}}$ \\
\hline 4 week & 0 & $60.1^{\mathrm{a}}$ & $59.9^{\mathrm{a}}$ & $45.8^{\mathrm{a}, \mathrm{b}}$ & $62.4^{\mathrm{a}}$ & $38.1^{\mathrm{b}}$ \\
\hline 6 week & 0 & $97.5^{\mathrm{a}}$ & $63.3^{\mathrm{b}, \mathrm{c}}$ & $72.5^{\mathrm{b}}$ & $79.1^{\mathrm{a}, \mathrm{b}}$ & $45.0^{c}$ \\
\hline
\end{tabular}

Seeds were fortified by soaking for $1 \mathrm{~h}$ in endophytic bacterial suspension of 0.1 OD prepared in water. Ral- CP and Ral+ CP: Ralstonia non-inoculated and inoculated cocopeat, respectively. EB 02, Bacillus pumilus; EB06, B. subtilis; EB07, B. flexus; EB 11, Enterobacter cloacae. Values followed by the same letter in a row are not significantly different; Ral- CP control treatment was not included in the statistical analysis for seedling mortality.

Ral- CP. The disease symptoms appeared by two weeks in control sick (Ral+) CP medium as wilting of seedlings (41\%) and the extent of mortality increased with time registering $52 \%$ by four weeks and $85 \%$ by six weeks. The four EB-treated sets showed relatively less disease incidence at 2 weeks but appeared almost on par with Ral+ control by 4 weeks. By 6 weeks, the EB-02 and EB-11 fortified sets offered some protection (33\% and 32\% survival, respectively) compared with Ral+ control (15\%). A second trial where the seed sowing was done on CP one week after the inoculation with the pathogen, relatively less disease incidence was observed with EB-seed fortified treatments (Table 3). On the other hand, a third trial employing freshly inoculated CP showed high disease incidence in the presence of endophytes on par with the Ral+ control while a fourth trial failed to show disease incidence indicating a loss in the virulence of the pathogen (data not shown).

\subsection{Assessing Selected Endophytes for Crop Protection at Transplanting}

The results from these trials indicated that the endophytes were able to offer some protection when the transplanting was undertaken to the sick soil as per the observations over six weeks (Figure 2(a)). The results were confirmed in a repeat trial where the seedlings were monitored for four weeks which indicated that while the EB isolates offered some protection, they were not effective in safeguarding the crop entirely from the pathogen (Figure 2(b)).

\subsection{Testing the Organisms for Any Direct Adverse Effects on Tomato Seedlings}

No obvious adverse effects were observed following petiole-excision inoculation of “Arka Vikas” seedlings with the endophytic isolates (Figure 3). The seedlings that were given inoculation with R. solanacearum showed 


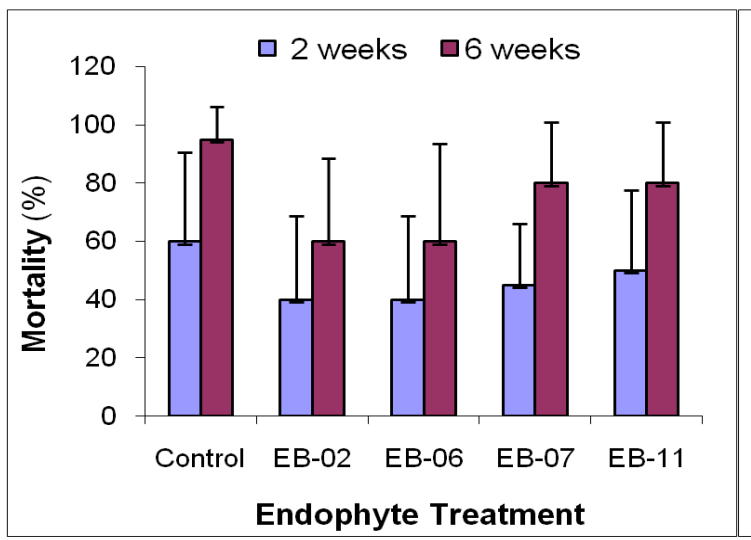

(a)

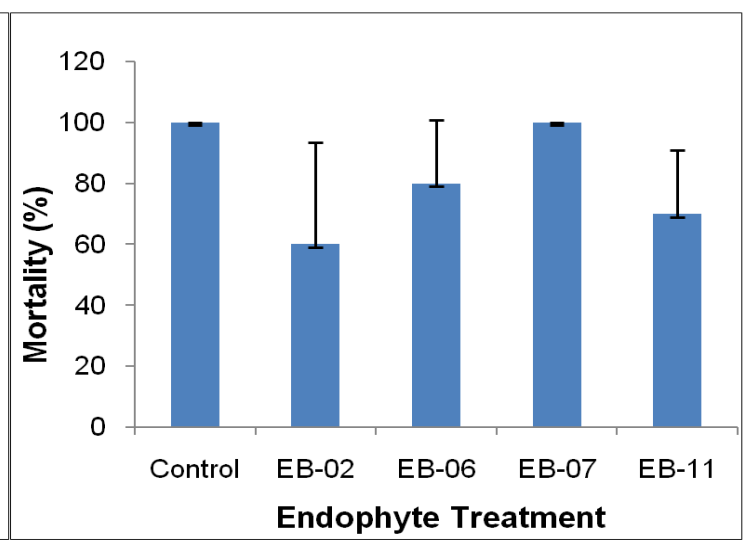

(b)

Figure 2. Assessing selected endophytic bacterial isolates for the ability to protect tomato crop by transplanting to Ralstonia freshly inoculated sick soil in protrays (a) or in soil inoculated with the pathogen one week prior to transplanting (b); Vertical bars indicate SD.

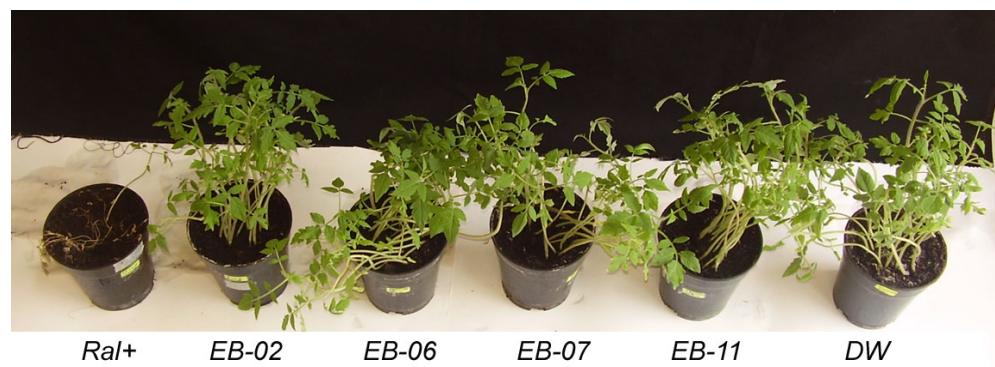

Figure 3. Testing the endophytic isolates for any direct adverse effects on tomato through petiole-excision inoculation; Ral+, Ralstonia inoculated set; EB-02, EB-06, EB-07 and EB-11, endophytic bacteria inoculated sets; DW, distilled water control.

quick disease development and high mortality.

\subsection{Testing the Organisms for Systemic Resistance Induction}

The seedlings that were transplanted to Ral+ sick soil following EB fortification through petiole-excision inoculation did not offer any advantage over control in terms of reducing the disease incidence; on the other hand, the extent of disease incidence appeared more than that in the control set (Figure 4(a)). The seedlings fortified through hypocotyl inoculation, however, offered some reduction in the extent of disease incidence during the next six weeks of monitoring, particularly with EB-02 and EB-06 (Figure 4(b)).

\subsection{Testing the Selected Organisms for Growth Promotion Effects on Tomato Seedlings}

Seed germination was unaffected except in EB-11 fortified treatment where a notable reduction in germination was observed (Table 4). Root growth in seedlings, which is a major indicator of the ability of the plants to perform in the field, was significantly more for the isolates EB-06, EB-07 and EB-11. The former two isolates also proved superior in terms of seedling shoot height, shoot weight and gross seedling weight over control although the differences were not significant in all the instances. Overall, the seedling growth was enhanced with EB-06 and EB-07 in comparison with the other treatments.

\section{Discussion}

The study identifies endophytic organisms from three unrelated crops of tomato, namely grape, papaya and watermelon, with antagonistic activity against the tomato wilt pathogen $R$. solanacearum. The above plant species 


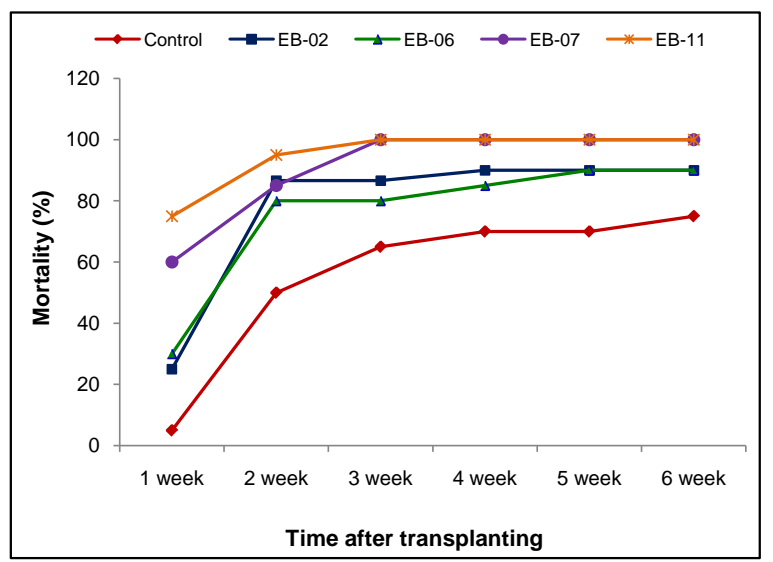

(a)

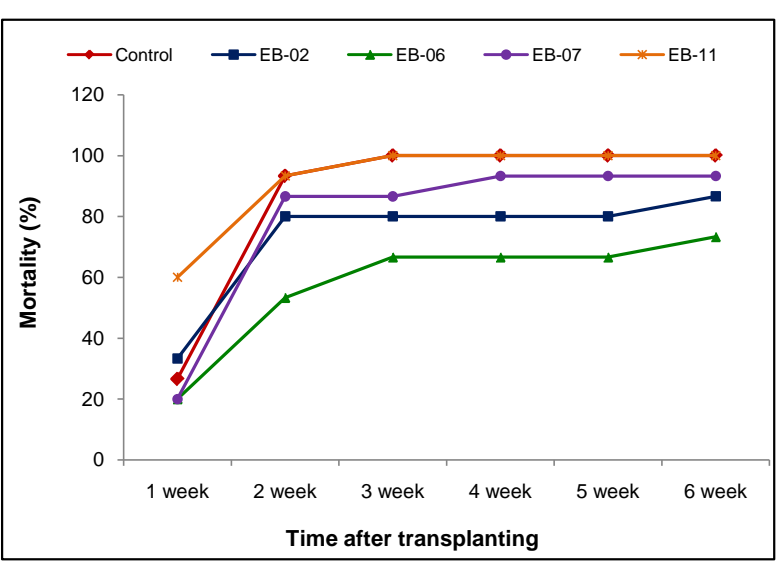

(b)

Figure 4. Testing the capability of endophytic organisms to induce systemic resistance to Ralstonia solanacearum through petiole excision inoculation (a) or through hypocotyl inoculation (b) before seedling transplanting to Ralstonia sick soil.

Table 4. Extent of seed germination and the growth characteristics of seedlings derived after seed fortification with the endophytic bacterial isolates by pre-sowing soaking inoculation.

\begin{tabular}{|c|c|c|c|c|c|}
\hline Endophytic isolate & Germination (\%) & Seedling height (cm) & $\begin{array}{c}\text { Shoot wt } \\
\text { (mg/seedling) }\end{array}$ & $\begin{array}{c}\text { Root wt } \\
\text { (mg/seedling) }\end{array}$ & $\begin{array}{l}\text { Seedling wt } \\
\text { (mg/seedling) }\end{array}$ \\
\hline EB02 & $85.0^{\mathrm{a}}$ & $23.3^{\mathrm{a}}$ & $1109^{\mathrm{a}}$ & $106^{\mathrm{a}}$ & $1216^{\mathrm{a}}$ \\
\hline EB06 & $87.5^{\mathrm{a}}$ & $29.5^{\mathrm{b}}$ & $1249^{\mathrm{a}}$ & $183^{\mathrm{b}}$ & $1432^{a, b}$ \\
\hline EB 07 & $90.0^{\mathrm{a}}$ & $29.9^{\mathrm{b}}$ & $1367^{\mathrm{a}}$ & $179^{\mathrm{b}}$ & $1546^{\mathrm{a}, \mathrm{b}}$ \\
\hline EB 11 & $72.5^{b}$ & $27.9^{\mathrm{b}}$ & $1084^{\mathrm{a}}$ & $156^{\mathrm{b}}$ & $1240^{\mathrm{a}}$ \\
\hline Non-inoculated Control & $92.5^{\mathrm{a}}$ & $27.5^{\mathrm{b}}$ & $1184^{\mathrm{a}}$ & $107^{\mathrm{a}}$ & $1314^{\mathrm{a}, \mathrm{b}}$ \\
\hline Significance & * & ** & NS & ** & NS \\
\hline $\mathrm{P}$ & 0.0261 & 0.0053 & 0.710 & 0.0042 & 0.238 \\
\hline $\mathrm{CD}(\mathrm{P}=0.05)$ & 10.57 & 3.02 & 370.3 & 42.45 & 274.6 \\
\hline
\end{tabular}

${ }^{*},{ }^{* *}$; significant at $\mathrm{P}=0.05$ and $\mathrm{P}=0.01$, respectively, NS, not significant. Values followed by the same letter in a column are not significantly different.

are not normally known to be the host to this pathogen for the exception of an isolated report on papaya [26]. As per the in vitro agar-diffusion assays, E. cloacae appeared the most promising among the four organisms with clear antagonistic activity. E. cloacae is a proteobacterium ( $\gamma$-subclass) similar to $R$. solanacearum ( $\beta$-subclass), and has been reported as an antagonist to R. solanacearum [11] [15] [30]. The other potentially useful organisms included B. pumilus, $B$. subtilis and B. flexus. Of these, $B$. subtilis has been reported as an antagonist and efficient biocontrol agent against R. solanacearum [31] [32]. B. pumilus is not normally known as a biocontrol agent against this pathogen. It is pertinent to note that only one of the three B. pumilus isolates (EB-02 from grape) showed clear inhibition-zone development while the other two isolates from watermelon did not show such consistent antagonistic effects. This suggests the strain specificity as an influencing factor during biocontrol approaches.

A genotype or crop species which is naturally susceptible to a pathogen may or may not be bearing the antagonistic organisms against the pathogen in question. This aspect is under our detailed investigations. As per Feng et al. [33], Ralstonia resistant tomato genotype possessed more cultivable and antagonistic endophytic bacteria than the susceptible check. Identification of antagonistic endophytes associated with crops that are genetically unrelated to tomato and not normally susceptible to the pathogen offers the scope for trans-crop introduction or horizontal transfer of organisms across plant species. It is likely that the same organisms may also form natural endophytes of tomato, but the strains in that event could be different. It is now envisaged to explore the resistant genotypes of tomato for the antagonistic organisms. In this respect, the observation by Feng et al. 
[33] that the resistant tomato genotypes possessed more cultivable and antagonistic endophytic bacteria than the susceptible check assumes significance.

Testing the different organisms for their ability to alleviate the disease incidence by introducing them through seed fortification just before sowing in sick soil offered some biocontrol effect particularly when the cocopeat medium was inoculated a week prior to the sowing rather than freshly inoculated sowing medium which is more akin to field sick soil. However, it was not possible to prevent the disease incidence entirely or save the crop wholly as is the case with other studies too where a significant reduction in disease incidence is often reported [9]-[15], [30]-[33]. The same was the impression from the transplanting trials to the sick soil at 4 week stage. In the normal course, it is possible to raise the seedlings under pathogen-free conditions. The seedlings normally come in contact with the pathogen at the time of field transplanting. A reduction in disease incidence would be advantageous as otherwise no harvestable crop is obtained from the wilt inflicted plants.

Although E. cloacae appeared the most effective organism as per the agar-diffusion assays, it did not prove so in comparison with the other organisms. E. cloacae being a proteobacterium, may be sensitive to the soil conditions and thus may not be a good rhizosphere competitor. On the other hand, members of Bacillus genus have the advantage of being hardy spore-formers which may help in preparing stable bioformualtions and they would form better candidates towards bio-control [10] [11] [31]. The spores may remain dormant during storage. However, they possess the ability to sense the environmental conditions and respond with germination with the return of favorable conditions [34]. In this respect, the three isolates EB-02, EB-06 and EB-07 proved advantageous. The isolates EB-06 and EB-07 also showed enhancement in root and gross seedling growths.

Although a number of organisms could be identified as potential antagonistic agents in in vitro screenings, the effectiveness may vary under soil conditions. Lack of consistency appeared to be a limitation with the use of antagonistic organisms in the glasshouse trials. The ability of the organism to survive in the bio-formulations, in rhizospheric soil or to colonize the plants may vary. This may be particularly so with the endophytes. Bio-control applications in the field have been limited by inconsistent disease control effects [9] [33]. It is generally observed that while a number of beneficial organisms are identified in the laboratory, a lower number are successful in glasshouse trials and still fewer function effectively under practical conditions [9] [35].

\section{Conclusion}

In conclusion, this study identifies four endophytic organisms from crops unrelated to tomato possessing potential antagonistic activity against the wilt pathogen with prospects for exploitation as biocontrol agents coupled with seedling growth promotion effects. It would now warrant more translational research to see how far these organisms are able to protect the tomato crop in the field.

\section{Acknowledgements}

The study was funded by the ICAR-AMAAS Net-work project on "Endophytic Microorganisms in Horticultural Crops" and the Institute Project 9.3.2 "Use of Endophytic Bacteria for Alleviating Ralstonia Wilt in Tomato". Technical help by N. Shivarudriaha and the support during some of the trials by Mujawar, Revathy and Aparna are gratefully acknowledged. The publication bears IIHR contribution No. 55/2014.

\section{References}

[1] Hayward, A.C. (1991) Biology and Epidemiology of Bacterial Wilt Caused by Pseudomonas solanacearum. Annual Review of Phytopathology, 29, 65-87. http://dx.doi.org/10.1146/annurev.py.29.090191.000433

[2] Elphinstone, J. (2005) The Current Bacterial Wilt Situation: A Global View. In: Allen, C., Prior, P., Hayward, A.C., Eds., Bacterial Wilt Disease and the Ralstonia solanacearum Species Complex, APS Press, St. Paul, 9-28.

[3] Genin, S. and Denny, T.P. (2012) Pathogenomics of the Ralstonia solanacearum Species Complex. Annual Review of Phytopathology, 50, 67-89. http://dx.doi.org/10.1146/annurev-phyto-081211-173000

[4] Patil, V.U., Gopal, J. and Singh, B.P. (2012) Improvement or Bacterial Wilt Resistance in Potato by Conventional and Biotechnological Approaches. Agricultural Research, 1, 299-316. http://dx.doi.org/10.1007/s40003-012-0034-6

[5] Chellemi, D.O., Dankers, H.A., Olson, S.M., Hodge, N.C. and Scott, J.W. (1994) Evaluating Bacterial Wilt-Resistant Tomato Genotypes Using a Regional Approach. Journal of American Society of Horticultural Science, 119, 325-329.

[6] Ji, P., Momol, M.T., Rich, J.R., Olson, S.M. and Jones, J.B. (2007) Development of an Integrated Approach for Man- 
aging Bacterial Wilt and Root-Knot on Tomato under Field Conditions. Plant Disease, 91, 1321-1326. http://dx.doi.org/10.1094/PDIS-91-10-1321

[7] Compant, S., Duffy, B., Nowak, J., Clément, C. and Barka, E.A. (2005) Use of Plant Growth-Promoting Bacteria for Biocontrol of Plant Diseases: Principles, Mechanisms of Action, and Future Prospects. Applied and Environmental Microbiology, 71, 4951-4959. http://dx.doi.org/10.1128/AEM.71.9.4951-4959.2005

[8] Backman, P.A. and Sikora, R.A. (2008) Endophytes: An Emerging Tool for Biological Control. Biological Control, 46, 1-3. http://dx.doi.org/10.1016/j.biocontrol.2008.03.009

[9] Tan, H., Zhou, S., Deng, Z., He, M. and Cao, L. (2011) Ribosomal-Sequence-Directed Selection for Endophytic Streptomycete Strains Antagonistic to Ralstonia Solanacearum to Control Tomato Bacterial Wilt. Biological Control, 59, 245-254. http://dx.doi.org/10.1016/j.biocontrol.2011.07.018

[10] Guo, J.H., Qi, H.Y., Guo, Y.H., Ge, H.L., Gong, L.Y., Zhang, L.X. and Sun, P.H. (2004) Biocontrol of Tomato Wilt by Plant Growth-Promoting Rhizobacteria. Biological Control, 29, 66-72. http://dx.doi.org/10.1016/S1049-9644(03)00124-5

[11] Nguyen, M.T. and Ranamukhaarachchi, S.L. (2010) Soil-Borne Antagonists for Biological Control of Bacterial Wilt Disease Caused by Ralstonia solanacearum in Tomato and Pepper. Journal of Plant Pathology, 92, 395-406.

[12] Maji, S. and Chakrabartty, P.K. (2014) Biocontrol of Bacterial Wilt of Tomato Caused by Ralstonia solanacearum by Isolates of Plant Growth Promoting Rhizobacteria. Australian Journal of Crop Science, 8, 208-214.

[13] Vanitha, S.C., Niranjana, S.R., Mortensen, C.N. and Umesha, S. (2009) Bacterial Wilt of Tomato in Karnataka and Its Management by Pseudomonas fluorescens. BioControl, 54, 685-695. http://dx.doi.org/10.1007/s10526-009-9217-x

[14] Ramesh, R. and Phadke, G.S. (2012) Rhizosphere and Endophytic Bacteria for the Suppression of Eggplant Wilt Caused by Ralstonia solanacearum. Crop Protection, 37, 35-41. http://dx.doi.org/10.1016/j.cropro.2012.02.008

[15] Achari, G.A. and Ramesh, R. (2014) Diversity, Biocontrol, and Plant Growth Promoting Abilities of Xylem Residing Bacteria from Solanaceous Crops. International Journal of Microbiology, 2014, Article ID: 296521. http://dx.doi.org/10.1155/2014/296521

[16] Rosenblueth, M. and Martinez-Romero, E. (2006) Bacterial Endophytes and Their Interactions with Hosts. Molecular Plant-Microbe Interactions, 19, 827-837. http://dx.doi.org/10.1094/MPMI-19-0827

[17] Thomas, P. (2011) Intense Association of Non-Culturable Endophytic Bacteria with Antibiotic-Cleansed in Vitro Watermelon and Their Activation in Degenerating Cultures. Plant Cell Reports, 30, 2313-2325. http://dx.doi.org/10.1007/s00299-011-1158-z

[18] Hallmann, J., Quadt-Hallmann, A., Mahaffee, W.F. and Kloepper, J.W. (1997) Bacterial Endophytes in Agricultural Crops. Canadian Journal of Microbiology, 43, 895-914. http://dx.doi.org/10.1139/m97-131

[19] Tans-Kersten, J., Huang, H. and Allen, C. (2001) Ralstonia solanacearum Needs Motility for Invasive Virulence on Tomato. Journal of Bacteriology, 183, 3597-3605. http://dx.doi.org/10.1128/JB.183.12.3597-3605.2001

[20] White, J.F., Torres, M.A., Somu, M.P., Johnson, H., Irizarry, I., Chen Q., Zhang, N., Walsh, E., Tadych, M. and Bergen, M. (2014) Hydrogen Peroxide Staining to Visualize Intracellular Bacterial Infections of Seedling Root Cells. Microscopy Research and Technique, 77, 566-573. http://dx.doi.org/10.1002/jemt.22375

[21] Thomas, P. and Sekhar, A.C. (2014) Live Cell Imaging Reveals Extensive Intracellular Cytoplasmic Colonization of Banana Genotypes by Normally Non-Cultivable Endophytic Bacteria. AoB PLANTS, 6, plu002. http://dx.doi.org/10.1093/aobpla/plu002

[22] Thomas, P. (2004) Isolation of Bacillus Pumilus from in Vitro Grapes as a Long-Term Alcohol-Surviving and Rhizogenesis Inducing Covert Endophyte. Journal of Applied Microbiology, 97, 114-123.

[23] Thomas, P. (2006) Isolation of an Ethanol-Tolerant Endospore-Forming Gram-Negative Brevibacillus sp. as a Covert Contaminant in Grape Tissue Cultures. Journal of Applied Microbiology, 101, 764-774. http://dx.doi.org/10.1111/j.1365-2672.2006.02993.x

[24] Thomas, P. (2007) Isolation and Identification of Five Alcohol Defying Bacillus spp. Covertly Associated with in Vitro Culture of Seedless Watermelon. Current Science, 92, 983-987.

[25] Thomas, P., Kumari, S., Swarna, G.K. and Gowda, T.K.S. (2007) Papaya Shoot Tip Associated Endophytic Bacteria Isolated from in Vitro Cultures and Host-Endophyte Interaction in Vitro and in Vivo. Canadian Journal of Microbiology, 53, 380-390. http://dx.doi.org/10.1139/W06-141

[26] Seshadri, K., Usman, K.M., Kandaswamy, T.K. and Seetharaman, K. (1977) Bacterial Wilt of Papaya Caused by Pseudomonas solanacearum. Madras Agricultural Journal, 64, 181-182.

[27] Thomas, P., Sadashiva, A.T., Upreti, R. and Mujawar, M.M. (2014) Direct Delivery of Inoculum to Shoot Tissue Interferes with Genotypic Resistance to Ralstonia Solanacearum in Tomato Seedlings. Journal of Phytopathology, Early View. http://dx.doi.org/10.1111/jph.12281 
[28] Kelman, A. (1954) The Relationship of Pathogenicity of Pseudomonas solanacearum to Colony Appearance in a Tetrazolium Medium. Phytopathology, 44, 693-695.

[29] Thomas, P. and Upreti, R. (2014) Influence of Seedling Age on Susceptibility of Tomato Plants to Ralstonia Solanacearum during Potray Screening and at Transplanting. American Journal of Plant Sciences, 5, 1755-1762. http://dx.doi.org/10.4236/ajps.2014.512190

[30] Xue, Q.Y., Chen, Y., Li S.M., Chen L.F., Ding, G.C., Guo, D.W. and Guo, J.H. (2009) Evaluation of the Strains of Acinetobacter and Enterobacter as Potential Biocontrol Agents against Ralstonia Wilt of Tomato. Biological Control, 48, 252-258. http://dx.doi.org/10.1016/j.biocontrol.2008.11.004

[31] Almoneafy, A.A., Xie, G.L., Tian, W.X., Xu, L.H. and Zhang, G.H. (2012) Characterization and Evaluation of Bacillus Isolates for their Potential Plant Growth and Biocontrol Activities against Tomato Bacterial Wilt. African Journal of Biotechnology, 11, 7193-7201.

[32] Yang, Y., Xu, Q., Liu, H.X., Wang, Y.P., Wang W.M., Yang, H.T. and Gou, J.H. (2012) Evaluation of Biological Control Agents against Ralstonia Wilt on Ginger. Biological Control, 62, 144-151. http://dx.doi.org/10.1016/j.biocontrol.2012.05.001

[33] Feng, H., Li, Y. and Liu, Q. (2013) Endophytic Bacterial Communities in Tomato Plants with Differential Resistance to Ralstonia solanacearum. African Journal of Microbiology Research, 7, 1311-1318.

[34] Setlow, P. (2014) Germination of Spores of Bacillus Species: What We Know and Do Not Know. Journal of Bacteriology, 196, 1297-1305. http://dx.doi.org/10.1128/JB.01455-13

[35] Lugtenberg, B. and Kamilova, F. (2009) Plant-Growth-Promoting Rhizobacteria. Annual Review of Microbiology, 63, 541-556. http://dx.doi.org/10.1146/annurev.micro.62.081307.162918 
Scientific Research Publishing (SCIRP) is one of the largest Open Access journal publishers. It is currently publishing more than 200 open access, online, peer-reviewed journals covering a wide range of academic disciplines. SCIRP serves the worldwide academic communities and contributes to the progress and application of science with its publication.

Other selected journals from SCIRP are listed as below. Submit your manuscript to us via either submit@scirp.org or Online Submission Portal.
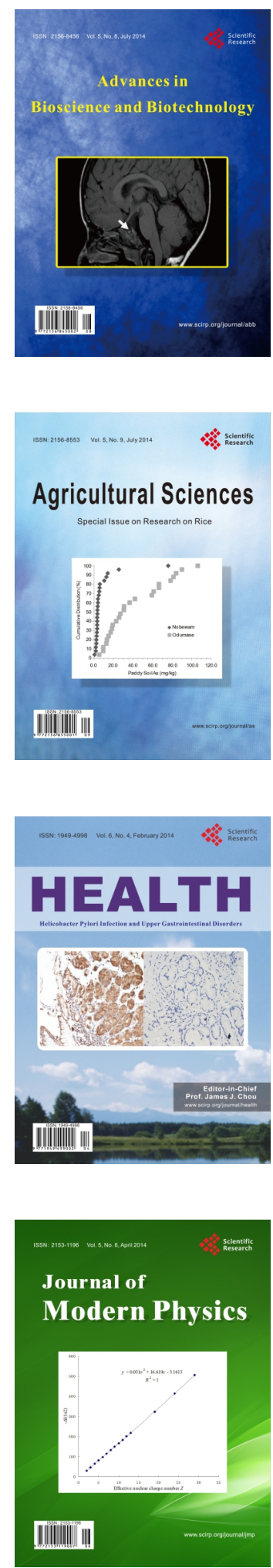
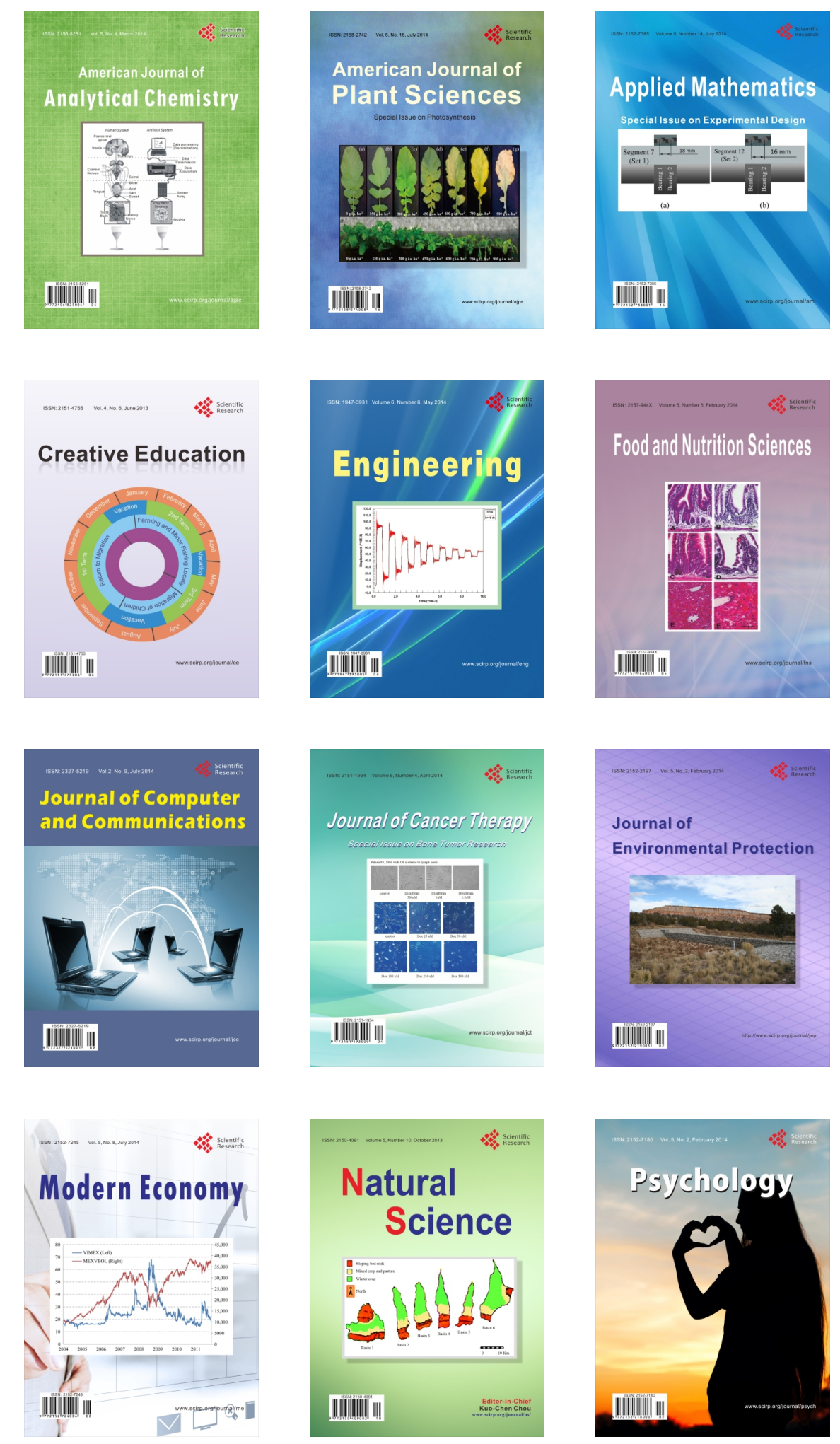